\title{
Pengaruh beban lampu terhadap tegangan, arus, dan rpm pada turbin angin savonius 2 sudu
}

\author{
Ahmadi $i^{\star}$, Mochamad Arif Irfa ${ }^{i}{ }^{2}$, Basuki ${ }^{3}$ \\ Prodi Teknik Mesin, Fakultas Teknik, Universitas Hasyim Asy'ari ${ }^{1,2,3}$ \\ JI. Irian Jaya 55 Tebuireng Tromol Pos IX Jombang Jatim Telp. (0321) 861719 (Hunting), \\ 864206, 851396, 874685 Fax. 874684 \\ Corresponding author: Ahmadi.kepung1996@gmail.com
}

\begin{abstract}
Nowadays using electrical energy in society is increasing. This is the cause for doing the work, people using tools machine that required a voltage source as a driver. The explanation to be basic for research about the conversion of wind energy to electrical with making vertical axis wind turbines. This research aims to figure out the effect of lamp load to voltage, current, and RPM on the 2 blades savonius wind turbine. This is experiment research. This research using quantitative descriptive analysis, with independent variables, are lamp loads 0, 3, 6, 9 Watts and the dependent variables are voltage, current, and RPM. Results obtained from testing then analysis and conclusion attract. Results research indicates the highest performance of savonius 2 blades wind turbine on 0 Watt lamp load it producing, 11.68 Volts, 0 Amperes, and 334.2 RPM. Lowest performance of 2 blades savonius wind turbine on 9 Watt lamp load producing, 7.68 Volts, 0.13 Amperes, and 272.9 RPM. Based on results on the test can conclude that the more lamp loads activated, voltage and RPM values decrease while, current value increases. This is because the number of lamp loads increases then, the amount of electric charge moving per unit of time also increases.
\end{abstract}

Keywords: wind turbine, voltage, current, and RPM.

\begin{abstract}
Abstrak
Penggunaan energi listrik di masyarakat sekarang semakin meningkat. Hal ini dikarenakan dalam menjalankan pekerjaan, manusia menggunakan alat bantu mesin yang memerlukan tegangan listrik sebagai penggeraknya. Penjelasan tersebut menjadi dasar melakukan penelitian tentang konversi energi angin menjadi listrik dengan membuat turbin angin vertical axis savonius. Tujuannya untuk mengetahui pengaruh beban lampu terhadap tegangan, arus, dan RPM poros pada turbin angin savonius 2 sudu. Jenis penelitian ini adalah experiment. Penelitian ini menggunakan analisis deskriptif kuantitatif dengan variabel bebasnya adalah beban lampu $0,3,6$, dan 9 Watt dan variabel terikatnya adalah tegangan, arus, dan RPM. Hasil yang diperoleh dari pengujian kemudian dianalisis dan ditarik kesimpulan. Hasil penelitian menunjukkan unjuk kerja tertinggi turbin angin savonius 2 sudu pada beban lampu 0 Watt menghasilkan tegangan 11,68 Volt, arus 0 Ampere, dan 334,2 RPM. Unjuk kerja terendah turbin angin savonius 2 sudu pada beban lampu 9 Watt menghasilkan tegangan 7,68 Volt, arus 0,13 Ampere, dan 272,9 RPM. Berdasarkan hasil pengujian dapat disimpulkan bahwa, semakin banyak beban lampu yang diaktifkan maka nilai tegangan dan RPM mengalami penurunan sedangkan, arus mengalami peningkatan. Hal ini disebabkan karena jumlah beban lampu yang meningkat maka, jumlah muatan listrik yang bergerak per satuan waktu juga meningkat.
\end{abstract}

Kata kunci: turbin angin, tegangan, arus, dan RPM. 


\section{Pendahuluan}

Bertambahnya jumlah penduduk di desa maupun kota mengakibatkan penggunaan energi listrik semakin meningkat. Meningkatnya penggunaan energi listrik tersebut disebabkan karena manusia menggunakan alat bantu mesin dalam melakukan aktifitas bekerja. Alat bantu mesin memerlukan sumber tegangan listrik sebagai penggeraknnya. Sumber tegangan listrik yang digunakan oleh manusia masih berasal dari energi yang tidak terbarukan seperti minyak bumi dan batubara. Hal tersebut yang menjadi dasar untuk melakukan pengembangan energi yang tersedia di alam sebagai energi alternatif terbarukan sehingga, menekan jumlah pemakaian sumber daya alam yang berasal dari bahan fosil yang sifatnya tidak terbarukan. Angin menjadi salah satu pilihan energi yang tepat untuk dikembangkan, diantara berbagai jenis sumber energi terbarukan lainnya karena sifat angin yang terbarukan dan ramah lingkungan [1,2].

Indonesia sangat kaya dengan energi alternatif terbarukan dan dapat digunakan untuk menghasilkan energi listrik contoh salah satu energi tersebut adalah energi angin. Angin di Indonesia masuk kategori kecepatan angin rendah, yaitu bernilai antara 2 m/detik sampai $6 \mathrm{~m} /$ detik. Kecepatan angin yang rendah sulit dikonversi menjadi energi listrik dalam jumlah yang besar. Meski seperti itu, energi angin di Indonesia hampir ada sepanjang tahunnya maka, memungkinkan dibangun pembangkit listrik tenaga angin skala kecil sampai dengan menengah [3,4].

Alat yang dirancang dan digunakan untuk mengubah bentuk dari energi kinetik angin menjadi energi mekanik pada poros, dan diubah menjadi energi listrik tersebut adalah turbin angin. Turbin angin terdapat beberapa macam model. Berdasarkan model poros, turbin angin terbagi atas dua model yaitu horizontal axis wind turbine dan vertical axis wind turbine. Turbin Angin vertical axis dibagi menjadi tiga tipe yaitu turbin angin darrieus, turbin $\mathrm{H}$, dan turbin angin savonius. Turbin angin savonius memiliki keunggulan yaitu cut in speed yang rendah, bentuk desain yang lebih sederhana, dapat berputar dengan menerima angin dari segala arah mata angin, dan generator terletak di bawah sehingga, mempermudah perawatan $[5,6]$.

Maka penulis tertarik mengerjakan penelitian mengenai turbin angin vertical axis savonius, dengan demikian penulis mengambil judul "Pengaruh beban lampu terhadap tegangan, arus, dan rpm pada turbin angin Vertical Axis Savonius 2 sudu". Diharapkan ke depanya ada penelitian untuk skala menengah sehingga, mampu membantu menutupi kebutuhan listrik masyarakat yang terus mengalami peningkatan.

\section{Tinjauan Pustaka}

Angin adalah udara yang bergerak dari udara bertekanan tinggi ke udara bertekanan rendah atau dari suhu rendah ke wilayah bersuhu tinggi karena pengaruh panas matahari yang tidak merata angin mengandung energi kinetik sebab udara mempunyai massa dan berkecepatan [7].

Turbin angin adalah serangkaian perangkat yang di fungsikan untuk merubah bentuk energi kinetik angin menjadi energi mekanik pada poros, poros tersebut dirangkai dengan gear box untuk memutar generator sehingga generator dapat menghasilkan tegangan listrik [2].

Gambar 1 menunjukkan sistem konversi energi angin.

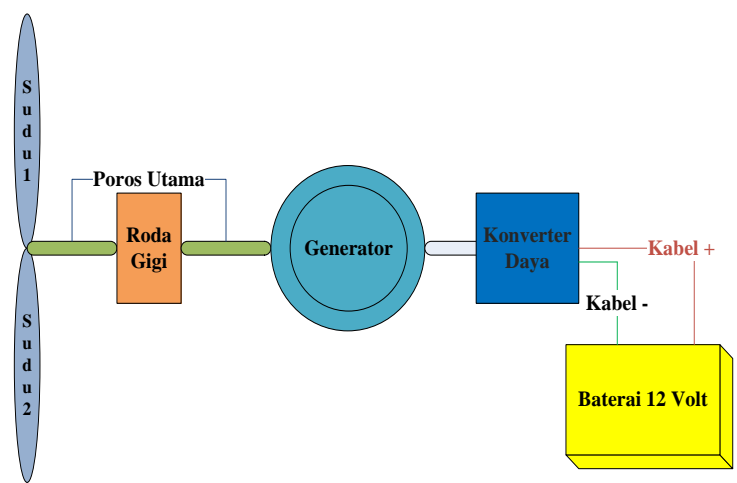

Gambar 1. Sistem Konversi Energi Angin 
Turbin angin adalah serangkaian alat yang dapat mengubah energi kinetik angin menjadi energi mekanik pada poros sudu kemudian disambungkan dengan poros generator yang dihubungkan sebuah gear box, putarannya gear box diteruskan untuk memutar generator sehingga generator menghasilkan energi listrik. Jenis model poros turbin angin terbagi menjadi dua yaitu horizontal axis wind turbine dan vertical axis wind turbine [6].

Turbin angin vertical axis adalah turbin angin dengan poros utama berdiri tegak terhadap permukaan tanah dan memiliki struktur yang lebih sederhana, dapat berputar dari segala arah angin serta memiliki self starting yang bagus. Turbin angin vertical axis memiliki beberapa jenis variasi yaitu savonius, darrieus dan turbin $\mathrm{H}$, turbin angin savonius memanfaatkan gaya hambat sedangkan, darrieus dan $\mathrm{H}$ memanfaatkan gaya angkat [5].

Turbin angin horizontal axis merupakan turbin yang posisi poros utamanya sejajar dengan tanah dan posisi generator diatas tower. Turbin tipe ini mempunyai sudu berbentuk airfoil sebagaimana model sayap pesawat terbang. Secara universal makin banyak jumlah sudu, makin tinggi juga RPM turbin.

Untuk mendapatkan hembusan angin yang maksimal pada turbin angin ukuran kecil cukup ditambahkan ekor yang menghadap searah dengan datangnya angin, sedangkan untuk turbin skala besar diperlukan sebuah sistem sensor angin yang digerakkan motor. Gaya yang bekerja pada unjuk kerja turbin ini adalah gaya angkat untuk pengelompokan turbin angin horizontal axis terbagi menjadi dua yaitu berdasarkan letak poros dan berdasarkan jumlah sudu [8].

Prinsip kerja turbin angin adalah mengkonversi energi kinetik angin menjadi energi mekanik poros kemudian dirubah menjadi energi listrik oleh generator. Turbin angin savonius ini tipe turbin yang memanfaatkan gaya hambat angin yang terdapat disudu-sudunya untuk memutar poros, sedangkan penjelasan dari gaya hambat adalah gaya yang bekerja berlawan arah dengan datangnya angin [2].

\section{Metode Penelitian}

Jenis penelitian ini adalah exsperimen. Penelitian ini menggunakan analisis deskriptif kuantitatif dengan variabel bebasnya adalah beban lampu dan variabel terikatnya tegangan, arus, dan RPM yang dihasilkan turbin angin vertical axis savonius 2 sudu. Hasil yang diperoleh dari pengujian kemudian dianalisis dan ditarik kesimpulan.

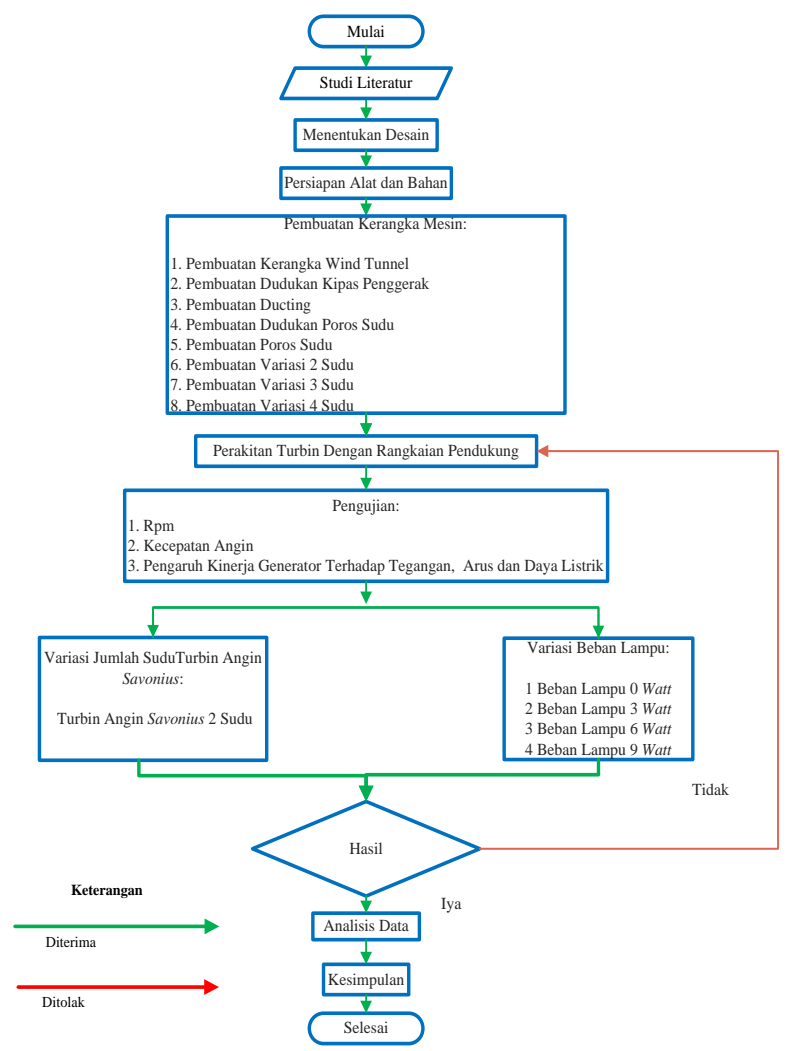

Gambar 2. Flow Chart Penelitian.

Variabel yang digunakan dalam penelitian ini adalah sebagai berikut:

1. Variabel bebas adalah variabel yang mempengaruhi perubahanya variabel terikat atau independent variable. Pada penelitian ini varibel bebasnya adalah beban lampu 0 Watt, 3 Watt, 6 Watt, dan 9 Watt.

2. Variabel terikat adalah variabel hasil variabel bebas atau dependent variable. Pada penelitian ini variabel terikatnya adalah tegangan, arus, dan RPM yang 
dihasilkan turbin angin vertical axis savonius 2 sudu.

3. Variabel kontrol adalah variabel yang di atur dan dikendalikan sehingga, pengambilan datanya dapat valid hasilnya sesuai rencana penelitian. Pada penelitian ini variabel kontrolnya adalah turbin angin jenis vertical axis savonius 2 sudu dengan panjang sudu $40 \mathrm{~cm}$, diameter sudu $18 \mathrm{~cm}$, alat ukur yang digunakan dalam pengambilan data tidak diganti, dan sudah di set up sebelumnya.

Gambar 3 menunjukkan desain turbin angin vertical axis savonius 2 sudu.

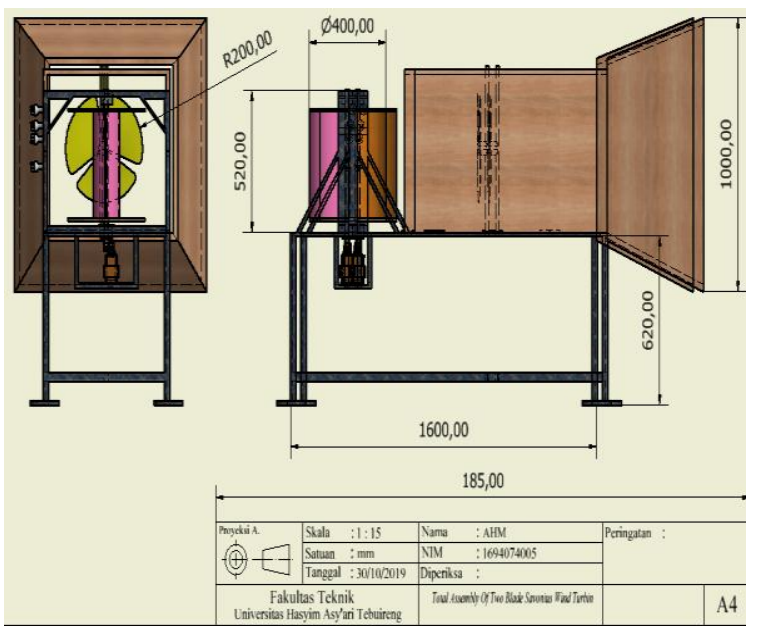

Gambar 3. Turbin Angin Vertical Axis Savonius 2 Sudu.

Penulis mengumpulkan data secara langsung dari referensi buku, jurnal dan lain sebagainya yang berkaitan dengan pengaruh beban lampu terhadap tegangan, arus, dan RPM yang dihasilkan turbin angin vertical axis savonius 2 sudu, dilanjutkan menetukan desain alat penulis meminta saran dan masukan kepada Bapak/Ibu dosen tentang gambar desainnya sehingga, hasil akhir perakitan dapat diperkirakan, dilanjutkan persiapan perkakas dan bahan yang akan dipakai dalam penelitian, dilanjutkan membuat kerangka mesin yang meliputi: (pembuatan kerangka wind tunnel, pembuatan dudukan kipas penggerak atau blower ventilator, pembuatan ducting, pembuatan dudukan poros sudu, penyenaian poros sudu, pembuatan 2 sudu, dilanjutkan perakitan keseluruhan part), dilanjutkan pengujian turbin angin savonius yang telah dibuat diantaranya meliputi pengujian kecepatan angin dengan menggunakan anemometer, setelah itu kecepatan putar turbin diukur dengan menggunakan tachometer, serta pengukuran tegangan dan arus listrik generator dengan AVOmeter, dengan pengujian beban lampu $0,3,6,9$ Watt, pencatatan hasil yang didapat dalam penelitian, kemudian data yang didapat dari penelitian dianalisa dan disebutkan kesimpulannya sesuai dengan hasil yang di dapat saat penelitan.

Pada penelitian ini pengumpulan data dikerjakan dengan pengujian turbin angin vertical axis savonius 2 sudu dan empat variasi beban lampu yaitu 0, 3, 6, 9 Watt.

Dalam penelitian ini analisis data yang digunakan adalah analisis deskriptif kuantitatif. Data tersebut didapatkan dari nilai kecepatan angin, tegangan, arus listrik, dan RPM.

\section{Hasil dan Pembahasan}

Hasil nilai kesemuanya dari pengujian turbin angin vertical axis savonius 2 sudu tertulis di Tabel 1.

Tabel 1. Nilai Tegangan, Arus, dan Putaran Poros Pada Turbin Angin Savonius 2 Sudu.

\begin{tabular}{ccccc}
\hline No. & $\begin{array}{c}\text { Beban } \\
\text { Lampu } \\
\text { (Watt) }\end{array}$ & $\begin{array}{c}\text { Tegangan } \\
\text { (Volt) }\end{array}$ & $\begin{array}{c}\text { Arus } \\
\text { (Ampere) }\end{array}$ & $\begin{array}{c}\text { Putaran } \\
\text { Poros } \\
\text { (RPM) }\end{array}$ \\
\hline 1 & 0 & 11,68 & 0 & 334,2 \\
\hline 2 & 3 & 9,24 & 0,07 & 303,3 \\
\hline 3 & 6 & 8,20 & 0,12 & 278,6 \\
\hline 4 & 9 & 7,68 & 0,13 & 272,9 \\
\hline
\end{tabular}

Berdasarkan Tabel 1, hasil pengujian turbin angin savonius 2 sudu pada beban lampu 0 Watt atau tanpa beban lampu menghasilkan nilai tegangan 11,68 Volt, arus yang dihasilkan adalah 0 Ampere karena tanpa ada beban lampu, dan putaran poros yang dihasilkan adalah 334,2 RPM. Pada saat pengujian dengan beban lampu 3 
Watt turbin angin savonius 2 sudu menghasilkan nilai tegangan 9,24 Volt, arus yang dihasilkan adalah 0,07 Ampere, dan putaran poros yang dihasilkan adalah 303,3 RPM. Pada saat pengujian dengan beban lampu 6 Watt turbin angin savonius 2 sudu menghasilkan nilai tegangan 8,20 Volt, arus yang dihasilkan adalah 0,12 Ampere, putaran poros yang dihasilkan adalah 278,6 RPM. Pada saat pengujian dengan beban lampu 9 Watt turbin angin savonius 2 sudu menghasilkan nilai tegangan 7,68 Volt, arus yang dihasilkan adalah 0,13 Ampere, putaran poros yang dihasilkan adalah 272,9 RPM. Berdasarkan keterangan di atas yang menunjukkan hasil pengujian turbin angin vertical axis savonius 2 sudu dengan beban lampu 0, 3, 6, dan 9 Watt dapat disimpulkan bahwa, semakin banyak beban lampu yang diaktifkan maka, nilai tegangan dan RPM mengalami penurunan sedangkan, nilai arus mengalami peningkatan. Hal ini disebabkan karena jumlah beban lampu yang meningkat maka, jumlah muatan listrik yang bergerak per satuan waktu juga menaik.

Hubungan beban lampu 0, 3, 6, dan 9 Watt terhadap tegangan listrik yang dihasilkan generator.

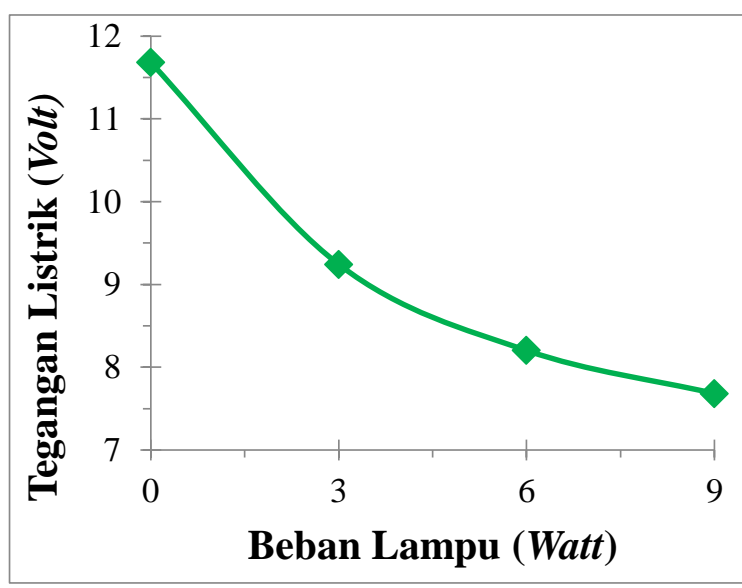

Gambar 4. Hubungan Beban Lampu Terhadap Tegangan Listrik

Berdasarkan Gambar 4 menunjukkan bahwa turbin angin savonius 2 sudu saat pengujian dengan beban $0 \mathrm{Watt}$ atau tanpa beban menghasilkan tegangan yang paling tinggi dengan nilai 11,68 Volt, pada saat pengujian beban lampu 3 Watt menghasilkan tegangan 9,24 Volt, pada saat pengujian beban lampu 6 Watt menghasilkan tegangan 8,20 Volt, dan tegangan terendah dihasilkan pada beban lampu 9 Watt sebesar 7,68 Volt. Semakin banyak beban lampu yang diaktifkan maka nilai tegangan mengalami penurunan.

Hubungan beban lampu 0, 3, 6, dan 9 Watt terhadap arus listrik.

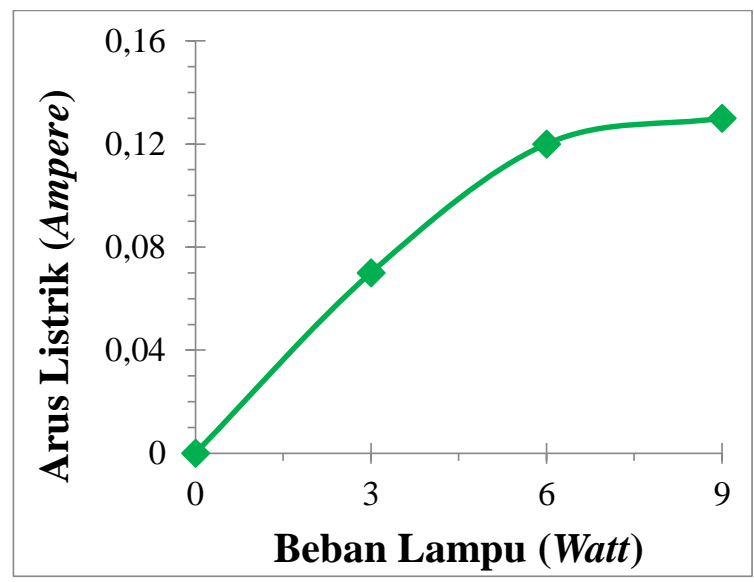

Gambar 5. Hubungan Beban Terhadap Arus Listrik.

Berdasarkan Gambar 5 menunjukkan bahwa, turbin angin savonius 2 sudu pada pengujian beban lampu 0 Watt atau tanpa beban lampu nilai arusnya adalah 0 Ampere, pada pengujian beban lampu 3 Watt nilai arusnya adalah 0,07 Ampere, pada pengujian beban lampu 6 Watt nilai arusnya adalah 0,12 Ampere, dan pada beban lampu 9 Watt nilai arusnya adalah 0,13 Ampere. Semakin banyak beban lampu yang diaktifkan maka arusnya mengalami peningkatan.

Hubungan Beban Lampu 0, 3, 6, dan 9 Watt terhadap RPM yang dihasilkan poros dapat dilihat pada Gambar 6 . 


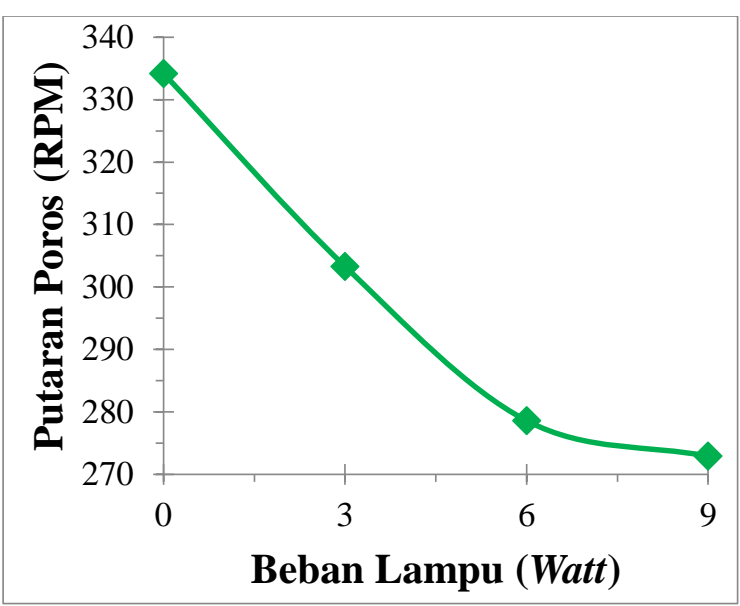

Gambar 6. Hubungan Beban Lampu Terhadap RPM

Berdasarkan Gambar 6 menunjukkan bahwa, turbin angin savonius 2 sudu pada pengujian beban lampu $0 \mathrm{Watt}$ atau tanpa beban lampu nilai tertinggi putaran porosnya adalah 334,2 RPM, pada pengujian beban lampu 3 Watt putaran porosnya adalah 303,3 RPM. pada pengujian beban lampu 6 Watt putaran porosnya adalah 278,6 RPM, dan nilai terendah putaran porosnya 272,9 RPM pada beban lampu 9 Watt. Semakin banyak beban lampu yang diaktifkan maka RPM mengalami penurunan.

\section{Kesimpulan}

Berdasarkan hasil pengujian dapat disimpulkan bahwa:

1. Unjuk kerja tertinggi turbin angin savonius 2 sudu pada beban lampu 0 Watt menghasilkan tegangan 11,68 Volt, arus 0 Ampere, dan 334,2 RPM.

2. Unjuk kerja terendah turbin angin savonius 2 sudu pada beban lampu 9 Watt menghasilkan tegangan 7,68 Volt, arus 0,13 Ampere, dan 272,9 RPM.

\section{Referensi}

[1]. Napitupulu, Farel H dan Siregar, Surya. 2013. "Perancangan Turbin Vertikal Axis Savonius Dengan Menggunakan 8 Buah Sudu
Lengkung". Jurnal Dinamis. Vol. 1 (13): hal. 24-36.

[2]. Ruzita Sumiati, Khairul Amri, Hanif. 2014. "Rancang Bangun Micro Turbin Angin Pembangkit Listrik Untuk Rumah Tinggal di Daerah Kecepatan Angin Rendah". Prosiding Seminar Nasional Sains dan Teknologi. Vol. 1 (1): hal. 1-5.

[3]. Sumiati, Ruzita dan Zamri, Aidil. 2013. "Rancang Bangun Miniatur Turbin Angin Pembangkit Listrik Untuk Media Pembelajaran”. Jurnal Teknik Mesin. Vol. 3 (2): hal. 1-8.

[4]. Rachman, Akbar. 2012. Analisis dan Pemetaan Potensi Energi Angin di Indonesia. Skripsi tidak diterbitkan. Depok: Program Sarjana Universitas Indonesia.

[5]. Nakhoda,Yusuf Ismail dan Saleh, Chorul. 2015. "Rancang Bangun Kincir Angin Sumbu Vertikal Pembangkit Tenaga Listrik Portabel". Seminar Nasional Sains dan Teknologi Terapan III. hal 59-68.

[6]. Wachid, Abdurrohman dan Siregar, Indra Herlamba. 2018. "Study Experimental Turbin Angin Savonius 2 tingkat Dengan Penambahan Drag Reducing Pada Returning Blade (Studi Kasus Pada 2 Blade Pertingkat)". Jurnal Pendidikan Teknik Mesin. Vol. 7 (1): hal. 78-82.

[7]. Pangestu, Rangga. dan Andriani, Sandri Ayu. 2017 https://www.researchgate.net/publicat ion/317529723_Turbin_Angin_Verti kal_Savonius_Bertingkat_Membentu k_Helix, Online, diakses 25 Desember 2019.

[8]. Sahid dan Priyoatmojo, Slamet. 2019. "Rancang Bangun Turbin Angin Poros Horizontal Tiga Sudu Flat 
Berlapis Tiga dengan Variasi Sudut dan Posisi Sudu". Jurnal Teknik Energi. Vol 15 (1): hal. 14-19. 